\title{
The Effect of Self-Efficacy on Employee's Organizational Commitment in a Private Chemical Industry
}

\author{
Kuganesh M Chendrasekaran, Umar Haiyat Abdul Kohar, Shah Rollah Abdul Wahab, \\ Mohammad Saipol Mohd Sukor, Nurul Farhana Mohd Noordin, Wan Mohd Azam Wan Mohd \\ Yunus.
}

\begin{abstract}
The chemical industries in Malaysia is one of the biggest industry and being one of the sources of income for Malaysians contributing to the nations' wealth for continuous development. To work in such industries requires high self-efficacy and an endless commitment by employees as chemical industries always deal with highly risk and hazardous substances. The aim of this study is to investigate the effect of self-efficacy on employees affective, continuance and normative commitment at a private chemical industry in Malaysia. This research employ survey method and a cross-sectional research design. A total of 80 respondents were recruited using simple random sampling method from a private chemical company in Johor. The data was collected using the general Self-efficacy Questionnaire and Organizational Commitment Questionnaire. The results shows that self-efficacy is at the high level while moderate level was recorded for all three affective, continuance and normative commitments among employees in the chemical company. Data analysis using simple linear regressions showed that self-efficacy predicted affective commitment, while self-efficacy did not significantly predicted continuance and normative commitments.
\end{abstract}

Keywords : Self-efficacy; affective commitment; continuance commitment; normative commitment.

\section{INTRODUCTION}

In the era of Industrial Revolution 4.0, Malaysia faces great economic growth and industrial development along with the

Revised Manuscript Received on October15, 2019.

* Correspondence Author

Kuganesh M Chendrasekaran, School of Human Resource

Development and Psychology, Faculty of Social Sciences and Humanities, Universiti Teknologi Malaysia. Email:

kuganesh_chendrasekaran@yahoo.com.

Umar Haiyat Abdul Kohar, Azman Hashim International Business School, Universiti Teknologi Malaysia, Johor, Malaysia. Email: wmohdazam@utm.my. Email: umarhaiyat@utm.my.

Shah Rollah Abdul Wahab, School of Human Resource Development and Psychology, Faculty of Social Sciences and Humanities, Universiti Teknologi Malaysia. Email: shah@management.utm.my

Nurul Farhana Mohd Noordin, School of Human Resource Development and Psychology, Faculty of Social Sciences and Humanities, Universiti Teknologi Malaysia. Email: nfarhana@utm.my

Mohammad Saipol bin Mohd Sukor, School of Human Resource Development and Psychology, Faculty of Social Sciences and Humanities, Universiti Teknologi Malaysia. Email.mohammadsaipol@utm.my.

Wan Mohd Azam Wan Mohd Yunus*, School of Human Resource Development and Psychology, Faculty of Social Sciences and Humanities, Universiti Teknologi Malaysia. Email: wmohdazam@utm.my. global market. According to the Department of Statistics Malaysia 2019 the growth registered in sales value in December 2018 was due to the increase in Transport Equipment and Other Manufactures Products (9.1\%), Electrical and Electronics Products (12.1\%) and Petroleum, and Chemical, Rubber and Plastic Products (5.0\%) [1]. In conjunction with that, it is proven that Malaysia's wealth is being contributed by one of the developed industries - the chemical industries.

A simple glance at a chemical plant, with its gleaming tanks and hissing smokestacks, makes it undoubtedly that working in such a location brings with it many hazards, including the potential for inhaling toxic fumes which can cause dangers to the employees and the possibility of fires or explosions that can cause serious injury or even death. Past research showed that it is possible for work environment to influence the perceptions of individual performance in completing their tasks [2] job satisfaction, and work performance [3]-[5]. Previous empirical studies have produced a number of research that indicated the positive relationship between self-efficacy and different motivational and behavioral outcomes in clinical [6], organizational [7], educational [8], [9], and banking [10] settings. Despite this, limited research on self-efficacy and organizational commitment conducted in the chemical industries.

Moreover, many factors contribute to differences in levels of self-efficacy and employee commitment. These factors include changes in economic climate, increased workload, alternating shifts, and long, consecutive hours [11]. One review also found that organizational commitment is lower among younger compared to older employees [12]. A large body of theoretical research conducted in both corporate and educational settings has indicated that higher levels of self-efficacy improve overall work performance and commitment [13]-[14]. Thus, the aim of this research is to examine the effect of self-efficacy on employee's organizational commitment at a chemical industry in Malaysia.

\section{MATERIALS AND METHODS}

This cross-sectional study utilises survey research design. The sample of this research is 80 employees recruited using convenience sampling method at a chemical company in the Southern region of Malaysia.

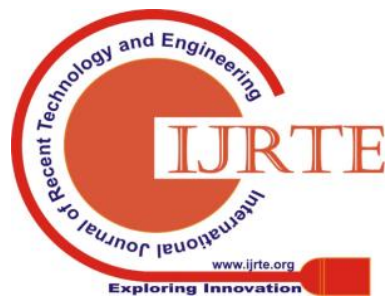


Self-efficacy was measured using the General Self-efficacy questionnaire developed by Schwarzer and Jerusalem [15] while organizational commitment was measured using the organizational commitment questionnaires by Allen and Meyer [16] in which consist of three dimensions; affective commitment, continuance commitment and normative commitment. The survey was distributed using Google Doc via employees' email address and the link was forwarded to their contact number. The Statistical Packages for Social Science (SPSS) was used to analyse the data.

Descriptive analysis was used to identify the demographics information, level of self-efficacy and level of organizational commitment. Moreover, simple linear regression was used to investigate the effect of self-efficacy towards the dimension of organizational commitment.

\section{RESULTS}

Majority of the respondents in this study were female, aging from 21 to 30 years old, have two to five years of working experience and the level of education is master degree. Table-I displays the result of overall mean scores of the variables. Self-efficacy recorded high level of mean scores while all three of affective, continuance and formative commitment recorded a moderate level of mean scores among the employees.

\section{Table-I: Self-efficacy, affective, continuance and} normative commitments among employees

\begin{tabular}{|l|c|c|c|}
\hline Variables & $\boldsymbol{M}$ & $\boldsymbol{S D}$ & Level \\
\hline Self-efficacy & 3.18 & 0.79 & High \\
\hline Affective commitment & 3.09 & 1.03 & Moderate \\
\hline Continuance commitment & 3.27 & 1.11 & Moderate \\
\hline Normative commitment & 3.19 & 1.14 & Moderate \\
\hline
\end{tabular}

A series of simple linear regressions was carried out to test if self-efficacy significantly predicted affective, continuance and normative commitments. The results of the regression are displayed in Table-II, Table-III and Table-IV. For overall, it was found that self-efficacy significantly explained six percents of the variance of affective commitment $\left(\mathrm{R}^{2}=0.06\right.$, $p<0.05)$. The results indicated that self-efficacy positively influence affective commitment in which the increase of one unit of self-efficacy will increase 0.24 units of affective commitment $(\beta=0.24, p<0.05)$. In contrast, no effect were recorded for self-efficacy towards continuance commitment, and normative commitment.

Table-II: Regression model on the effect of self-efficacy towards organisational commitment

\begin{tabular}{|c|l|c|c|c|}
\hline \multicolumn{2}{|l|}{ Model } & \multicolumn{3}{|c|}{ Affective commitment } \\
\hline \multicolumn{2}{|l|}{} & $\beta$ & $t$ & Sig. \\
\hline Self-efficacy & 0.24 & 2.13 & 0.04 \\
\hline $\mathrm{R}$ & 0.24 & & & \\
$\mathrm{R}^{2}$ & 0.06 & & & \\
$\mathrm{~F}$ & $4.55^{*}$ & & & \\
\hline
\end{tabular}

Table-III: Regression model on the effect of self-efficacy towards continuance commitment

\begin{tabular}{|c|c|c|c|c|}
\hline \multicolumn{2}{|l|}{ Model } & \multicolumn{3}{|c|}{ Continuance commitment } \\
\hline \multicolumn{2}{|c|}{} & $\beta$ & $t$ & Sig. \\
\hline Self-efficacy & 0.011 & 0.098 & 0.922 \\
\hline $\mathrm{R}$ & 0.011 & & & \\
$\mathrm{R}^{2}$ & 0.000 & & & \\
\hline
\end{tabular}

\begin{tabular}{|c|c|c|c|}
\hline $\mathrm{F}$ & 0.010 & & \\
\hline *significance level $p<0.05$ &
\end{tabular}

Table-IV: Regression model on the effect of self-efficacy towards normative commitment

\begin{tabular}{|c|c|c|c|c|}
\hline \multicolumn{2}{|l|}{ Model } & \multicolumn{3}{|c|}{ Normative commitment } \\
\hline \multicolumn{2}{|l|}{} & $\beta$ & $\mathrm{t}$ & Sig. \\
\hline Self-efficacy & 0.126 & 1.121 & 0.266 \\
\hline $\mathrm{R}$ & 0.235 & & & \\
$\mathrm{R}^{2}$ & 0.055 & & & \\
$\mathrm{~F}$ & 1.257 & & & \\
* & \multicolumn{4}{l}{} \\
\hline
\end{tabular}

\section{DISCUSSION}

The purpose of this study is to explore the effect of self-efficacy on employee's affective, continuance, normative commitments at a chemical industry. It was found that self-efficacy was at the high level, while moderate level was recorded for all three affective, continuance and normative commitments. Notably, results indicated that self-efficacy have a significant effect towards affective commitment and no significant effect towards continuance and normative commitment. The overall mean score for the level of self-efficacy among employees at this chemical company is recorded as high level. From the findings we can see that most of the employees have agreed that they can solve the problem if they put necessary effort. This is in line with a previous study that self-efficacy is synonymous with task-based self-esteem [17]. It can be referred to how individuals judge their abilities to organize and carry out course of action required to achieve pre-determined performance. The concept of self-efficacy itself provides the basis for motivating individuals and personal fulfillment of a task.

Moderate level of affective commitment was recorded among the employees. Allen and Meyer [16] stated that organizational commitment is one in which commitment is considered an affective or emotional attachment to the organization such that the strongly committed individual identifies with, is involved, and enjoys membership in the organization. It was argued that employees who have high levels of organizational identification have enhanced their sense of belonging to organization and are more psychologically attached to it [18]. On the other hand, many employees who have strong affective commitment continue to work in the organization because they prefer to. When employees perceive that "their" organization acts as a "true organization", they form positive images about it They feel proud to identify with such an organization, develop their self-efficacy, form affective bonds with the organization and make efforts to perform better [19].

Likewise, continuance commitment was also at the moderate level. From this finding, it can be discovered that most of the employees agreed that, working in an organization is a prerequisite to lead a normal life so that, they have to work in any field even though the career path is not their choices. This is consistent with a previous study that suggested continuance commitment is considered to be a passive commitment in which employee stays with organization because he or she has no other option to choose [20]. Moreover, Meyer [21] also stressed that continuance commitment has negative correlation with desirable work behavior.

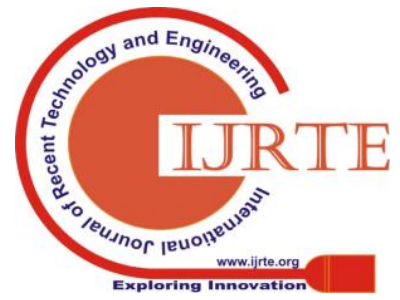


It is the willingness of employees to remain in organization because of fear of losing the benefits employee is acquiring from the job.

Similarly, the employees also show moderate level of normative commitment. From this finding, it is clearly understood that, employees are mostly spend most of their time at workplace only for the work and obligation to do so and not for the company's popularity. Normative commitment refers to person's feelings of obligation to stay with the organization. In other words, employees remain in the organization because they ought to do so. It is proposed that normative commitment is influenced by person's experiences both before and after entering the organization. This means that not only organizational socialization but also socialization that occurs in the families and society at large also affects how employee's normative commitment develops [16]-[22].

Self-efficacy is a person's evaluation of his ability or competence to do a task, achieve goals, and overcome obstacles. It refers to the belief in an individual's ability to move motivation, cognitive abilities, and actions needed to meet the demands of the situation [23]. While for affective commitment can be best described as the tendency of a worker to stay with a company that is based on an emotional attachment. An employee who displays affective commitment to their company will often identify strongly with the company and its objectives, and might turn down offers to move to a new company, even if they seem more attractive financially.

Based on the finding, a person with high self-efficacy tend to possess high sense of affective commitment. This is because a person that are emotionally attached to the organization has higher tendency to be more efficient and believe that they can achieve the goal and mission if they try their best towards any task or difficulties. Employees are strongly committed to several work targets, not other things, based on their willingness to accept the organizational values, strategies and their strong will to work for the organization's success and to stay within the organization [24]. A previous research also found out that to build organizational commitment there is a psychological connection between a person and his work based on an affective reaction to his position [25]. With this background it can be assumed that employees' self-efficacy contributes to affective commitment.

Secondly, the findings also shown that there are no significant effect of self-efficacy towards continuance commitment. This is mostly because of the nature of continuance commitment itself where the continuance commitment occurs when individuals base their relationship with the organization on what they are receiving in return for their efforts and what would be lost if they were to leave (e.g. pay, benefits from the organizations) [26]. These individuals put forth their best effort only when the rewards match their expectations and view the organization as a place to generate money. So, they will not have a high self-efficacy towards the organization and will not utilize their abilities and capabilities in order to perform well in their company.

Then, the last finding of simple regression analysis for self-efficacy and normative commitment also shown that there is no significant effect between both variables. The norm of normative commitment itself shown it occurs when individuals remain with an organization based on expected standards of behavior or social norms so, when the organization itself not as per their expected regulations and norms then the effect of self-efficacy of an employee towards the organization also will not as per the organizations standard [26]. When there is lack of normative values within an employees and organization then the employees self-efficacy will be low and their performance will not be magnificent.

\section{CONCLUSION}

As a conclusion, the findings of this research showed that self-efficacy is at the high level, while affective, continuance and normative commitments are a t the moderate level among employees in this chemical company. Moreover, self-efficacy was found to be is a significant predictor for affective commitment, but is not a significant predictor of continuance and normative commitment in a private chemical industry in Malaysia.

\section{REFERENCES}

1. Department of Statistics Malaysia. Monthly Manufacturing Statistics Malaysia, December 2018. 2018.

2. Donald I, Taylor P, Johnson S, Cooper C, Cartwright S, Robertson S Work environments, stress, and productivity: An examination using ASSET. Int J Stress Manag. 2005;12(4):409-23.

3. Jex SM, Bliese PD. Efficacy beliefs as a moderator of the impact of work-related stressors: a multilevel study. J Appl Psychol. 1999 Jun;84(3):349-61.

4. Lankau MJ, Scandura TA. An Investigation of Personal Learning in Mentoring Relationships: Content, Antecedents, and Consequences. Acad Manag J [Internet]. 2002;45(4):779-90. Available from: http://www.jstor.org/stable/3069311

5. Xiao W, Zhou L, Wu Q, Zhang Y, Miao D, Zhang J, et al. Effects of person-vocation fit and core self-evaluation on career commitment of medical university students: the mediator roles of anxiety and career satisfaction. Int J Ment Health Syst. 2014 Feb;8(1):8.

6. Bandura A, Adams NE, Hardy AB, Howells GN. Tests of the generality of self-efficacy theory. Cognit Ther Res. 1980;4(1):39-66.

7. Wood R, Bandura A. Social cognitive theory of organizational management. Acad Manag Rev. 1989;14(3):361-84.

8. Schunk DH. Self-efficacy and education and instruction. In: Self-efficacy, adaptation, and adjustment: Theory, research, and application. New York, NY, US: Plenum Press; 1995. p. 281-303. (The Plenum series in social/clinical psychology.).

9. Zeb S, Nawaz A. Impacts of Self-Efficacy on Organizational Commitment of Academicians. Inf Knowl Manag. 2016;6(1):36-42.

10. Srivastava S, Pathak P. Impact of Self-Efficacy, Organizational Commitment and Job Involvement on Job Performance in Private Bank Employees. In: Proceedings of 10th International Conference on Digital Strategies for Organizational Success. 2019.

11. Garcia GF. The Relationship Between Self-Efficacy and Employee Commitment Among Perfectionists. Walden University; 2015.

12. Aziz, K. A., Rahman, R. H. A., Yusof, H. M., \& Yunus, W. M. A. W. M. A Review on Generational Differences and Work-related Attitude. International Journal of Academic Research in Business and Social Sciences 2018; 8(8), 346-360.

13. Bandura A. Self-efficacy: The exercise of control. Self-efficacy: The exercise of control. New York, NY, US: W H Freeman/Times Books/ Henry Holt \& Co; 1997. ix, 604-ix, 604.

14. Meyer JP, Allen NJ. A three-component conceptualization of organizational commitment. Hum Resour Manag Rev [Internet] 1991;1(1):61-89. Available from: http://www.sciencedirect.com/ science/article/pii/105348229190011Z

15. Schwarzer R, Jerusalem M. Generalized Self-Efficacy scale. In Weinman J, Wright S, Johnston M, editors. Measures in health psychology: A user's portfolio Causal and control beliefs. Windsor, UK: NFER-NELSON; 1995. p. 35-7.

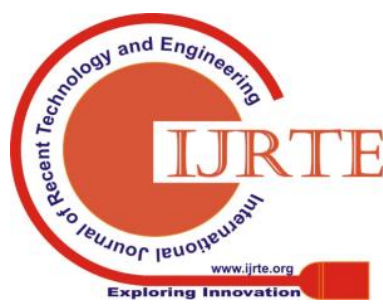


16. Allen NJ, Meyer JP. The measurement and antecedents of affective, continuance and normative commitment to the organization. J Occup Psychol [Internet]. 1990 Mar 1;63(1):1-18. Available from: https://doi.org/10.1111/j.2044-8325.1990.tb00506.x

17. Lent RW, Brown SD. Integrating person and situation perspectives on work satisfaction: A social-cognitive view. J Vocat Behav [Internet]. 2006;69(2):236-47. Available from: http://www.sciencedirect.com/science/article/pii/S0001879106000169

18. Lee S, Lee TW, Choon-Fong L. The effects of employee serviceson organizational commitmentand intentions to quit. Pers Rev. 2008;37(2):222-37.

19. Sayğan FN. Relationship between affective commitment and organizational silence: A conceptual discussion. Int J Soc Sci Humanit Stud. 2011;3(2):219-27.

20. Hiroaki I. Relationship among individual-level computerization, organizational commitment, and job performance. In: PICMET '01 Portland International Conference on Management of Engineering and Technology Proceedings Vol1: Book of Summaries (IEEE Cat No01CH37199). 2001. p. 323 vol.1.

21. Meyer JP, Stanley DJ, Herscovitch L, Topolnytsky L. Affective, Continuance, and Normative Commitment to the Organization: A Meta-analysis of Antecedents, Correlates, and Consequences. J Vocat Behav [Internet]. 2002;61(1):20-52. Available from: http://www.sciencedirect.com/science/article/pii/S0001879101918421

22. Markovits Y, Boer D, van Dick R. Economic crisis and the employee: The effects of economic crisis on employee job satisfaction, commitment, and self-regulation. Eur Manag J [Internet]. 2014;32(3):413-22. Available from: http://www.sciencedirect.com/science/article/pii/S0263237313001151

23. Bandura A. Self-Efficacy [Internet]. The Corsini Encyclopedia of Psychology. 2010. p. 1-3. (Major Reference Works). Available from: https://doi.org/10.1002/9780470479216.corpsy0836

24. Morin AJS, Meyer JP, McInerney DM, Marsh HW, Ganotice FA. Profiles of dual commitment to the occupation and organization: Relations to well-being and turnover intentions. Asia Pacific J Manag [Internet]. 2015;32(3):717-44. Available from: https://doi.org/10.1007/s10490-015-9411-6

25. Canrinus ET, Helms-Lorenz M, Beijaard D, Buitink J, Hofman A. Self-efficacy, job satisfaction, motivation and commitment: exploring the relationships between indicators of teachers' professional identity. Eur J Psychol Educ [Internet]. 2012 Mar;27(1):115-32. Available from: https://doi.org/10.1007/s10212-011-0069-2

26. Meyer JP, Allen NJ. Commitment in the workplace: Theory, research and application. California: Sage; 1997.

\section{AUTHORS PROFILE}

Kuganesh M Chendrasekaran was a postgraduate student for Master of Science in Human Resource Development at the School of Human Resource Development \& Psychology, Faculty of Social Sciences and Humanities, Universiti Technology Malaysia.

Umar Haiyat Abdul Kohar is a senior lecturer at the Azman Hashim International Business School, Johor Bahru Campus, Universiti Teknologi Malaysia. He completed his bachelor's and master's degrees from Universiti Teknologi MARA (UiTM) Shah Alam and a Ph.D. degree from RMIT University, Australia. His research interests are in the area of entrepreneurship, innovation management, and education.

Shah Rollah Abdul Wahab is a senior lecturer at the School of Human Resource Develeopment \& Psychology, Universiti Technology Malaysia. He obtained his Ph.D in Management from Universiti Technologi Malaysia. He is with UTM for more than 17 years and currently active in research related to Safety Management, Transformational Leadership and Employee Training

Mohammad Saipol bin Mohd Sukor is a senior lecturer at Schoold of Human Resource Development and Psychology (SHARPS), Universiti Teknologi Malaysia. He graduated with a PhD in Management (2018) and Bachelor Degree in Psychology (2012) from Universiti Teknologi Malaysia. Currently, he involved actively in teaching, research and consultation. His area of expertise are Stress Management, Work-related Attitudes and Behaviors and Positive Psychology.

Nurul Farhana Mohd Noordin is a senior lecturer in the Department of Psychology, School of HRD and Psychology, Universiti Teknologi
Malaysia. She received her doctoral degree in 2016 and her research fields are organisational behaviour, positive psychology and social psychology.

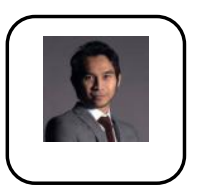

Wan Mohd Azam Wan Mohd Yunus is a senior lecturer in psychology at the School of Human Resource Development \& Psychology, Faculty of Social Sciences and Humanities, Universiti Technology Malaysia. He obtained his Ph.D in Clinical Psychology at King's College London, UK and M.Clin.Psych at Universiti Kebangsaan Malaysia. He is currently active in research related to digital mental health, clinical psychology and abnormal psychology. 